\title{
An ICCA Evaluation Function, or \\ a Self-Referential Statement, or \\ the Treasurer's Report
}

\author{
Jonathan Schaeffer \\ ICCA Secretary/Treasurer
}

The ICCA was founded 10 years ago to further the interest in computer chess. It is a non-profit organization that relies on its membership to sustain it. The most visible component of the organization is its quarterly publication, the ICCA Journal. In the years that I have been a member of the ICCA, the Journal has grown from a small newsletter to a 64 page quality publication that our organization can be proud of.

One of my first tasks as treasurer of the ICCA was to determine the financial state of our organization. Since the ICCA is run by volunteers, this is essentially equivalent to determining the financial viability of producing the ICCA Journal. To the best of my knowledge, this has not been done in recent memory.

The task of completing the financial statements was hampered by several problems:

1) For 1986, there were three sources for accounting data: Jaap van den Herik and his staff at the Delft University of Technology, Delft, The Netherlands (where the Journal is produced); Bill Blanchard (treasurer 1983-1986), and myself at the University of Alberta, Edmonton, Canada (taking over from Bill midway through 1986). Each source had different accounting practices.

2) The ICCA funds are in three currencies (Dutch guilders, United States dollars, and Canadian dollars) giving rise to the usual problems of fluctuating exchange rates.

Figure 1 gives the 1986 ICCA Profit and Loss statement and Figure 2, the Balance Sheet at year end, March 1, 1987. The figures are expressed in United States dollars and have been rounded to the nearest $\$ 50$. The bottom line is that the ICCA lost a lot of money last year, and (barring significant changes), will continue to do so.

Profit \& Loss Statement

(United States Dollars)

\begin{tabular}{|l|lr|r|r|}
\hline Income: & Journal sales & $\$ 8050$ & & \\
& Interest & 300 & & \\
& Miscellaneous & 50 & & \\
\hline Expenses: & Postage & & $\$ 5650$ & \\
& Delft service & & 1450 & \\
& Production & & 8500 & \\
& Supplies & & 50 & \\
& Miscellaneous & & 50 & \\
& & $-\ldots-{ }^{2}$ & \\
& & $\$ 8400$ & $\$ 15700$ & \\
\hline Net loss for 1986: & & & \multicolumn{3}{|c|}{$\$ 7300$} \\
\hline
\end{tabular}

Figure 1 
To make matters worse, there are several serious problems with the figures as shown:

1) No accurate records have been kept that break income down into sales of back issues, 1986 subscriptions, and 1987-and-beyond subscriptions. Because of this, income is overstated since a portion of it contains 1987 renewals. This income should be applied to defray 1987 costs, not 1986.

2) Subscription income and postage expenses are probably overstated by a few hundred dollars. Previous bookkeeping practices equated income with bank deposits. Postage was paid in advance and anything left over was refunded to the ICCA - appearing as a deposit and according to this statement, income.

3) The numbers represent the combination of the three ICCA accounts in three currencies expressed in United States dollars. As such, some numbers will vary with the fluctuating exchange rates.

4) Journal production and mailing is done through the University of Alberta and Delft University of Technology. Both Universities are slow in billing their services. The Profit and Loss statement includes the actual and estimated costs for all issues of the 1986 ICCA Journal. In particular, the figures reflect the estimated cost of producing the December 1986 issue.

5) Bill Blanchard has loaned the ICCA $\$ 4000$ of which we have paid back $\$ 1500$.

6) Income is almost exclusively from subscriptions to the ICCA Journal. Table 1 shows the membership of the ICCA, a far cry from the 700 members claimed on the inside cover of the December 1986 issue of the Journal. "Gratis" memberships are mainly to two groups of people: honorary ones for past achievements in computer chess, and publicity ones given to individuals or groups who can publicize our organization (chess magazines, science writers, newspapers, etc).

Balance Sheet

(United States Dollars)

\begin{tabular}{|c|c|c|c|}
\hline Assets: & $\begin{array}{l}\text { Cash - Europe } \\
\text { Cash - North America }\end{array}$ & $\begin{array}{r}\$ 12750 \\
1600\end{array}$ & \\
\hline Liabilities: & $\begin{array}{l}\text { Blanchard loan } \\
\text { University of Alberta } \\
\text { Delft }\end{array}$ & $\$ 14350$ & $\begin{array}{r}2500 \\
200 \\
15650 \\
-\$ 18350\end{array}$ \\
\hline \multicolumn{4}{|r|}{$\$ 4000$} \\
\hline
\end{tabular}

Figure 2

\begin{tabular}{|c|c|c|c|}
\hline \multicolumn{4}{|c|}{ ICCA Journal distribution } \\
\hline Type & Europe & $\begin{array}{c}\text { North } \\
\text { America }\end{array}$ & Total \\
\hline Subscribers & 231 & 220 & 451 \\
\hline Gratis & 62 & 11 & 73 \\
\hline Total & 293 & 231 & 524 \\
\hline
\end{tabular}

Table 1

The previous discussion emphasizes the fact that better accounting practises must be enforced. Steps to do this are already under way. At best, the numbers presented in the statements (particularly income) can be viewed as approximate figures. 
Obviously the ICCA is losing money and some action is required. I do not want to editorialize, but the following discussion outlines some possibilities for improving our financial state. The ICCA executive will have to meet and decide on a course of action.

1) The obvious solution is to increase membership dues. At the last triennial ICCA meeting (Cologne, June 1986), it was voted to increase membership dues from $\$ 15$ to $\$ 20$ US. A quick glance at Figure 1 shows that a $33 \%$ increase in income that the membership fee increase generates is still insufficient to break even. Also, note that the $\$ 20$ fee holds through 1989 (the next ICCA meeting), whereas expenses can be expected to increase.

2) 1200 copies of each issue of the ICCA Journal are produced. One could cut costs by producing less copies. However, most of the production costs for the Journal in Figure 1 are for preparation, not printing. Reducing the number of Journals printed per issue may save an estimated $\$ 500$ per year.

3) The Journal is mailed directly to European subscribers from Delft. A bundle of 300 Journals is sent to me at the University of Alberta, which in turn I send to our North American subscribers. It is fairly inexpensive for me to mail the Journal to our North American membership, and for Delft to send it to our European membership. However, most of the postal expenses $(\$ 700-\$ 800$ per issue) are in sending the Journals from Delft to Alberta. The alternative is to mail the Journal directly from Delft to all subscribers. Unfortunately, postal rates are such that this is only slightly cheaper. This area is currently under investigation.

4) The least desirable solution is to reduce the size (number of pages) and weight of each issue of the Journal. This will reduce production and postal costs.

5) The best solution is to increase our membership. In the past 8 months, ICCA membership has increased $15 \%$, largely due to the publicity of the World Computer Chess Championship. We have to keep this momentum going!

6) Along with the best solution or indeed along with all desirable ones, a sponsor (or sponsors) might be sought who, possibly in exchange for their mention as sponsor in a conspicuous place in the Journal, may be willing to contribute toward the losses. It is understood that the mention of sponsorship should never degenerate to advertisements.

The ICCA executive will be meeting after the Advances in Computer Chess Conference at Noordwijkerhout, the Netherlands, at the end of April. Hopefully something constructive will come out of that meeting.

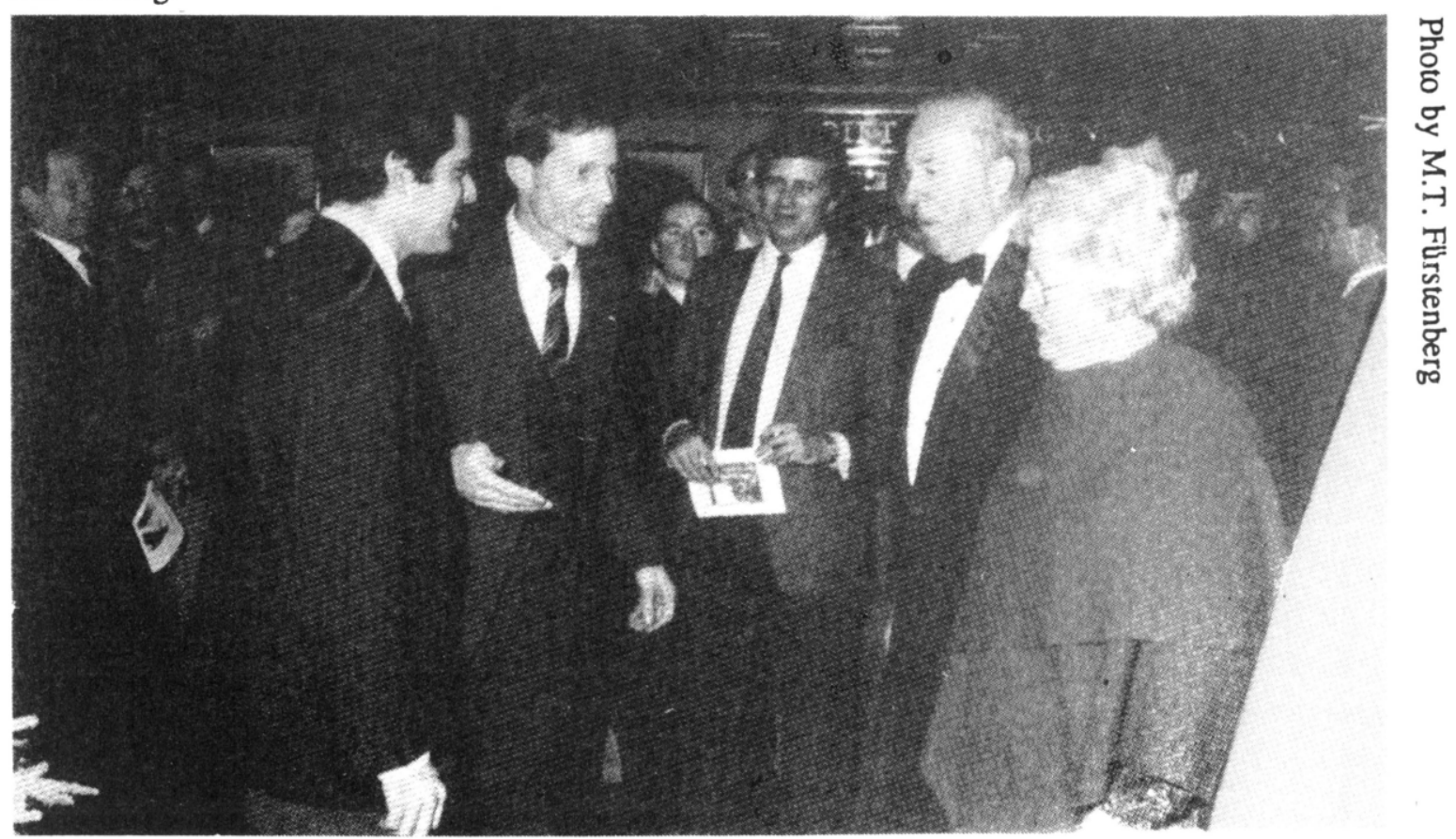

AN EAST - WEST DIALOGUE GEORGE: "WILL A COMPUTER....?" GARY
Secretary of State George Shultz quizzing Gary Kasparov (Brussels, December 1986) 